\title{
СОПОСТАВИТЕЛЬНОЕ ЯЗЫКОЗНАНИЕ, КОНТРАСТИВНАЯ ЛИНГВИСТИКА И ЛИНГВОДИДАКТИКА
}

\section{COMPARATIVE LINGUISTICS, CONTRASTIVE LINGUISTICS AND LINGUODIDACTICS}

\section{K. Gafiullina}

Summary: The purpose of this article, related to comparative linguistics and learning technology, is to study the application of the results of theoretical research in the practice of teaching a foreign language. The result of this work shows that contrastive research in the context of comparative linguistics contributes to the effectiveness of teaching foreign languages. But a differentiated approach to the use of comparison is necessary depending on the stage of learning a new language. Currently, the acquisition of a foreign language by comparison is influenced by the knowledge of several languages, both related and unrelated.

Keywords: comparative linguistics, contrastive linguistics, native language, foreign language, bilingualism.
Гафиуллина Кадрия Накиповна

к.филол.н., дочент, Казанский филиал ФГБОУ ВО «Российский государственный университет правосудия»

(2. Казань)

Gafiullina.kn@yandex.ru

Аннотация: Целью данной статьи, связанной с сопоставительной лингвистикой и технологией обучения, является изучение вопроса применения результатов теоретических исследований в практике преподавании иностранного языка. Результат проделанной работы показывает, что контрастивные исследования в контексте сопоставительного языкознания способствуют эффективности обучения иностранным языкам. Однако необходим дифференцированный подход к использованию сопоставления в зависимости от этапа изучения нового языка. В настоящее время на освоение иностранного языка методом сопоставления оказывает влияние владение несколькими языками, как родственными, так и неродственными.

Ключевые слова: сопоставительное языкознание, контрастивная лингвистика, родной язык, иностранный язык, билингвизм.
$\mathrm{B}$ активно развивающемся в направлении глобализации современном обществе оправдан рост интереса к сопоставительным исследованиям в языкознании. С каждым днем растет потребность людей в обмене социально значимой, профессиональной и научной информацией на разных языках и для этого требуются определенные навыки. В связи с этим увеличивается спрос на эффективные и понятные методики обучения иностранным языкам, учебники, разговорники, словари, способствующие оперативному и результативному усвоению нового языка.

Сравнение языков в общем языкознании осуществляется по двум направлениям: сравнительное языкознание (компаративистика) и сопоставительное языкознание (контрастивистика, контрастивная лингвистика, сопоставительная лингвистика). Первое направление связано со сравнением родственных языков главным образом в историческом ракурсе с определением языка-прародителя, общих корней, исторических изменений в фонетике, грамматике и т.п. Задачей второго направления является сопоставительное изучение нескольких (обычно двух) языков в синхронном ракурсе. Сравнительное языкознание является источником контрастивистики. С лингводидактикой больше связано сопоставительное языкознание.

Сопоставительное языкознание - лингвистическое направление, занимающееся изучением родственных или неродственных языков методом сравнения (сопоставления) их друг с другом с целью обнаружения сходств и различий их языковых подсистем на всех языковых уровнях. Проф. И.А. Стернин отмечает, что, несмотря на указание лингвистов, работающих в рамках сопоставительного метода, на возможность практического применения результатов их исследований в преподавании соответствующих языков, данное направление по существу остается преимущественно теоретическим. «Практическое применение результатов автономного сопоставительного описания одноименных подсистем двух языков не может быть непосредственно использовано в практике преподавания», поскольку «...практику преподавания не интересует сама системная организация микросистем, иерархия единиц, так как все это не является предметом практического обучения языку», - отмечает он [Стернин И.А., 2006, с. 11]. Для использования результатов сопоставительного анализа языков, преподаватель должен полученный теоретический сопоставительный материал осмыслить и проработать для подачи в удобной для обучения форме исходя из целей, задач и этапов обучения.

В конце XX века как отдельное лингвистическое направление начинает обособляться контрастивная лингвистика, которая до этого считалась синонимом сопоставительного языкознания. Функция контрастивной лингвистики заключается в связи между фундаментальной теоретической лингвистикой и прикладными аспек- 
тами языкознания, особенно лингводидактическими. Разграничение понятий контрастивного и сопоставительного языкознания основано на том, что сопоставительное языкознание имеет теоретический характер, в то время как контрастивная лингвистика в большей степени связана с прикладной отраслью языкознания переводом и преподаванием иностранного языка, а именно, его лингводидактическим аспектом. Контрастивный анализ ограничивается только двумя языками целевым (иностранным) и родным, тогда как при сопоставительном языкознании сравниваются любые языки в любом количестве для выявления как сходств, так и различий. Контрастивная лингвистика занимается выявлением лишь межъязыковых различий. На практике в лингводидактике для лучшего понимания и усвоения нового языка нельзя обойтись без учета языковых универсалий, сходств между новым и родным языками.

На стыке теории и практики обучения языку перед преподавателем встает множество вопросов: насколько достижения сопоставительного языкознания способствуют решению лингводидактических задач и как их эффективно использовать в процессе обучения иностранному языку; какие законы управляют процессами осмысления языковых контрастов в то время, когда теория языка пересекается с практикой его применения и преподавания; какова связь теоретических концепций контрастивной лингвистики с практикой межкультурных контактов; для каких целей может использоваться метод сравнения и что он может дать для решения проблем практического характера в освоении нового языка.

Научное специальное сопоставительное исследование языков профессиональными лингвистами нацелено на выяснение особенностей и контрастов языков, представление их обыденному пользователю, изучающему язык для реализации коммуникативных задач. Сравнение производится по отраслям сопоставительного языкознания. Наиболее развитым из них является сопоставительная грамматика (В.Н. Ярцева, В.Д. Аракин, В.Б. Кашкин и др.). Немало работ представлено по сопоставительной лексикологии, фонологии (В.Г. Гак, Р.О. Якобсон, И.А. Стернин, М.А. Стернина), развивается направление сопоставительной дискурсологии (3.Я. Тураева, В.Я. Мыркин, В.Б. Кашкин и др.). Несмотря на это нельзя сказать, что практическое использование результатов исследований контрастивной лингвистики относится к достаточно разработанным проблемам лингводидактики.

Сопоставление языков представляет интерес не только для лингвистов - профессионалов, как теоретиков, так и практиков, но часто происходит в быту: обыденный человек оказывается в ситуации, когда ему необходимо передать свою мысль иностранцу средствами чужого языка. Невольно он делает это, опираясь на средства своего родного языка, не всегда озабочиваясь тем, что- бы усвоить и соблюдать все грамматические правила в целевом языке, узнавая о них что называется «на ходу», когда ему указывают на ошибки. Бытовое соотнесение языков также проводится при переводе и изучении иностранных языков. Таким образом, сопоставление языков происходит на трех разных плоскостях (уровнях), в зависимости от категории пользователя:

1. обыденным человеком;

2. изучающим язык школьником, студентом и др.;

3. профессиональным лингвистом-исследователем. Каждый из них качественно по-разному совершает это, исходя из своих целей и задач.

Прежде всего, следует отметить, что усвоение иностранного языка взрослым проходит иначе, нежели усвоение языка (иногда сразу двух и трех языков) ребенком. Последний это делает механически, без определенной цели и вне определенных временных рамок, тогда как взрослым человеком иностранный язык усваивается с осознанием потребности в изучении, с определенной целью и зачастую в ограниченных временных рамках. Поэтому у каждого начинающего изучать язык взрослого человека возникают вопросы о том, каков наиболее эффективный и результативный способ усвоения языка (чтение литературы, просмотр сериалов на изучаемом языке и т.п.), какой учебник лучше, с чего начать и т.д.

Значение сопоставительного изучения языков для усвоения иностранного языка лингвистами оценивается по-разному. Некоторые специалисты считают, что языковые контрасты мешают усвоению нового языка, другие - наоборот, что способствует. Академик Л.В. Щерба придавал этому большое значение и писал, что сопоставление языков способствует лучшему пониманию не только чужого, но и своего родного языка [Цитата по: Стернин И.А., 2006, С.12]. Он считал, что родной язык не может быть изгнан из голов учащихся, и не надо изгонять его с урока, но использовать там, где он полезен [Щерба, 2004, C.62]. Освоение целевого языка предусматривает овладение новыми способами выражения мыслей на неродном языке, поэтому в данном процессе необходим осмысленный, сознательный подход. Согласно исследованиям американского лингвиста Д. Болинджера, языковые контрасты родного и иностранного языков в определенных случаях мешают усвоению другого языка: «Контрастная лингвистика родилась из опыта преподавания. Каждый преподаватель иностранного языка знает, а каждый изучающий иностранный язык скоро обнаруживает, что родной язык в определенных и предсказуемых случаях мешает усвоению второго языка. Запас преподавательских ухищрений сводится главным образом к преодолению таких помех». [Цит.по: Ярцева 1981, c. 4]. В практике преподавания бытует также мнение, что при изучении иностранного языка необходимо исключить использование родного языка для того, чтобы полностью погрузиться в новую языковую среду. С этой 
целью к обучению языку привлекаются так называемые «носители языка» - «native speakers», необязательно с лингвистическим образованием, часто не владеющих или плохо владеющих родным языком обучающегося.

Однако практика показывает, что на начальном этапе освоения иностранного языка сопоставительный аспект особенно важен, он категорически необходим как база, опора. Но на более продвинутом этапе, когда уже усвоены основные правила целевого языка, излишнее обращение к родному языку начинает мешать, а не помогать в совершенствовании, в переходе на уровень мышления на изучаемом языке. На данном этапе целесообразно в обучении постепенно перейти на использование только целевого языка.

Путь формирования вторичной языковой личности в процессе освоения целевого языка неизбежно сопровождается совершением обучаемым так называемых «ошибок» и их исправлением преподавателем. Существуют разные точки зрения преподавателей на это явление. С целью не смутить обучающего и не снизить его стремление выучить новый язык рекомендуется не акцентировать внимание на ошибках. М. Дебренн называет ошибки обучаемого даже положительным явлением в процессе изучения языка [Дебренн М., 2006, с. 5], и предлагает называть их «девиациями» (отклонениями от нормы) [цитата по Кашкин В.Б., 2007, с. 7]. Проф. В.Б. Кашкин отмечал, что «в последние годы в части лингвистических работ, связанных с технологией обучения и с сопоставительной лингвистикой, сформировалось направление, которое по-русски можно было бы назвать «ошибковедение» (error analysis). Он считал, что ошибки - это несовпадения двух сталкивающихся в сознании обучающегося языковых систем. [Кашкин В.Б., 2007, с. 7,8]. Таким образом, ошибки предлагаются рассматривать как девиантное (отклоняющееся) языковое поведение, отражающее языковые контрасты, расхождения двух языковых систем, а не «неуспеваемость» обучающегося. В итоге в процессе сопоставления языков на первый план выходит не сам язык, а индивид, точнее, индивиды, объединенные по сходству социальных языков, соответственно, и ошибок.

Процесс сопоставления при изучении нового языка сопровождается явлением лингвистической интерференции - последствием влияния одного языка на другой, т.е. применением норм одного языка в другом в письменной и/или устной речи. В зависимости от того, в какой области языкознания проявляется наложение норм, выделяются звуковая, орфографическая, грамматическая, лексическая, семантическая, стилистическая, внутриязыковая интерференции. Нередко в речи билингва происходят не только отклонения на целевом языке, происходящие под влиянием родного, но и интеркаляция - отклонения в речи на родном языке под влиянием иностранного.
В последнее время все большее распространение получает явление билингвизма и трилингвизма как в России, так и за рубежом. Как известно, Россия является страной с большим языковым многообразием. В решении задачи сохранения и развития межнационального и межкультурного согласия, воспитания подрастающего поколения быть готовым воспринимать разные языки и культуры в своей родной стране языковая проблема является одной из ключевых. В системе образования в России изучается около 100 языков. Государственная языковая политика РФ направлена на сохранение и развитие как государственного, так и родного языка всех народов, населяющих ее, а также создание условий для изучения языков международного значения.

В отечественном языкознании достаточно много теоретических и прикладных исследований, посвященных изучению языковых сходств и различий русского языка и языков национальных меньшинств в сопоставительном аспекте. В настоящее время все большее количество русскоязычного населения овладевает английским языком и изучает дополнительно, как правило, французский, немецкий, итальянский либо испанский языки. Поэтому при изучении нового языка на практике для лучшего усвоения материала возможно сопоставление языковых явлений трех (четырех) языков.

В научной литературе приводятся данные о положительной связи между билингвизмом и изучением иностранного языка [Cenoz, 2013b]). Например, проведенные исследования на территории Республики Татарстан и Чувашии свидетельствуют о том, что двуязычие является позитивным фактором для образовательных достижений, особенно в изучении английского языка (Tovar-García E. D. (2014), Tovar-García, Alòs i Font, 2017,). Те же закономерности этими исследователями выявлены применительно к носителям каталанского, галисийского и баскского языков в Испании и носителям турецкого языка в Бельгии. Исследователи объясняют это тем, что у полилингвов лучше развиты определенные когнитивные способности, например, исполнительного контроля [Bialystok, 2011], производительности памяти (Brito N.H., Sebastián-Gallés N., Barr R. (2015), восприятия речи [Rutgers, Evans, 2017]. Это подтверждается и экспериментальными данными: в ходе когнитивно-скринингового тестирования мыслительных способностей пожилые мультилингвы показали более высокие результаты, чем трилингвы, которые, в свою очередь, превзошли билингвов [Kavé, 2008]. Позднее появилось исследование, опровергающее наличие убедительных доказательств положительной связи между трилингвизмом или билингвизмом и образовательными достижениями. (Hèctor Alòs i Font, Edgar Demetrio Tovar-García (2018). Однако авторы исследований, в которых результаты противоречат данным более ранних исследований об обнаружении положительной связи билингвизма и трилингвизма с ака- 
демической успешностью, не твердо убеждены в своих заключениях. Они предполагают, что различия в результатах объясняются тем, что их исследование проведено в сельской среде, а предшествующие - на городских выборках. В то же время результаты свидетельствуют, что свободное владение двумя-тремя языками не оказывает негативного влияния и не снижает образовательные достижения обучающихся. Тем не менее, преимущество в освоении нового языка билингвами, трилингвами (полилингвами) есть и оно заключается в том, что у владеющих несколькими языками есть возможность сравнения языковых средств нового языка с более чем одним языком.

В целях обеспечения отвечающего современным требованиям, конкурентоспособного образования на трех языках (русском, татарском, английском) в Республике Татарстан планируется создать сеть шести новых полилингвальных образовательных комплексов, взаимодействующих с международной системой «Ассоцииррованных школ ЮНЕСКО [https://sntat.ru/news/science/03-04-2019/ polilingvalnye-shkoly-shaymieva-obuchenie-na-trehyazykah-internat-dlya-vunderkindov-i-filosofiyasoglasiya-5646642]. Языки в данной сети рассматриваются не только как предмет, а как средство обучения. Для этого потребуются применение передовых образовательных практик, программы обмена опытом, единая методика обучения, идущая с дошкольного полилингвального образования, учебно-методические комплексы, подготовленные педагогические кадры, способные компетентно вести образовательный процесс на иностранном языке, включая учителей-предметников неязыкового цикла. По словам зачинателей проекта, на начало реализации модели полилингвального образования основной проблемой является незнание английского языка как мирового языка общения. Наряду с образовательной, не менее важной задачей проекта является воспитание обучающихся в духе межнационального согласия.

В настоящее время на освоение иностранного языка методом сопоставления оказывает влияние владение несколькими языками, как родственными, так и неродственными. В этом случае сопоставительный анализ не ограничивается только двумя языками - целевым (иностранным) и родным (например, наряду с русским языком, при ознакомлении с оборотом used to или артиклями при изучении английского языка можно прибегнуть к схожим темам многократного прошедшего времени и винительного падежа в татарском языке). Таким образом, с интенсивным развитием явлений билингвизма, трилингвизма, полилингвизма ожидается, что вновь обратят на себя внимание вопросы сопоставительного языкознания, контрастивной лингвистики и лингводидактики.

\section{ЛИТЕРАТУРА}

1. Дебренн М. Французский язык в речевой практике русских. Межъязыковая девиатология / М. Дебренн. - Новосибирск : Новосиб. Гос.ун-т, 2006. - 386 с.

2. Кашкин В.Б. Сопоставительная лингвистика: Учебное пособие для вузов. - Воронеж: 2007. - 88 с.

3. Стернин И.А. Контрастивная лингвистика. Проблемы теории и методики исследования. М.: «Восток-Запад», 2006 г. - С. 11 (206 с.)

4. Щерба Л.В. Языковая система и речевая деятельность. Москва: Едиториал УРСС, 2004. - 432 с.

5. Ярцева В.Н. Контрастивная грамматика. М., 1981. - 111 с.

6. https://sntat.ru/news/science/03-04-2019/polilingvalnye-shkoly-shaymieva-obuchenie-na-treh-yazykah-internat-dlya-vunderkindov-i-filosofiyasoglasiya-5646642

7. Bialystok E. (2011) Reshaping the Mind: The Benefits of Bilingualism. Canadian Journal of Experimental Psychology/Revue Canadienne de Psychologie Expérimentale, vol. 65, no 4, pp. 229-235. doi:10.1037/a0025406

8. Brito N.H., Sebastián-Gallés N., Barr R. (2015) Differences in Language Exposure and its Effects on Memory Flexibility in Monolingual, Bilingual, and Trilingual Infants. Bilingualism: Language and Cognition, vol. 18, no 4, pp. 670-682. doi:10.1017/S1366728914000789

9. Cenoz J. (2013b) The Influence of Bilingualism on Third Language Acquisition: Focus on Multilingualism. Language Teaching, vol. 46, no 1, pp. 71-86. doi:10.1017/ S0261444811000218

10. Hèctor Alòs i Font \& Edgar Tovar-García (2018) Trilingualism, Bilingualism and Educational Achievements: The Case of Chuvash and Tatar in Rural Russia,» Educational Studies», Higher School of Economics, issue 3, pages 8-35.

11. Kavé G., Eyal N., Shorek A., Cohen-Mansfield J. (2008) Multilingualism and Cognitive State in the Oldest Old. Psychology and Aging, vol. 23 , no 1, pp. 70-78. doi:10.1037/0882-7974.23.1.70

12. Rutgers D, Evans M. (2017) Bilingual Education and L3 Learning: Metalinguistic Advantage or Not?' International Journal of Bilingual Education and Bilingualism, vol. 20, no 7, pp. 788-806. doi:10.1080/13670050.2015.1103698

13. Tovar-García E.D. (2014) Determinants of Educational Outcomes: Analysis of the Republic of Tatarstan. Communist and Post-Communist Studies, vol. 47, no 1, pp. 39-47. doi:10.1016/j.postcomstud.2014.01.001

14. Tovar-García E.D., Alòs i Font H. (2017) Bilingualism and Educational Achievements: The Impact of the Language Used at Home by Tatar School Students in Tatarstan, Russia. Journal of Multilingual and Multicultural Development, vol. 38, no 6, pp. 545-557. doi:10.1080/01434632.2016.1213847

(c) Гафиуллина Кадрия Накиповна (Gafiullina.kn@yandex.ru).

Журнал «Современная наука: актуальные проблемы теории и практики» 